\title{
SELEÇÃO E MULTIPICAÇÃO DE FUNGOS MICORRÍZICOS ARBUSCULARES PARA PRODUÇÃO DE MUDAS PARA AGRICULTURA FAMILIAR
}

\author{
Vera Lúcia Boff'; Andréa Hentz de Mello² \\ ${ }^{1}$ Discente do curso de Agronomia, Faculdade de Ciências Agrárias de Marabá (FCAM), Universidade Federal do Pará \\ (UFPA), Marabá, Pará. Bolsista PIBIC Interior. E-mail: veralboff@ hotmail.com. \\ ${ }^{2}$ Prof. ${ }^{\text {, }, ~ D . S c ., ~ F C A M, ~ U F P A . ~ E-m a i l: ~ a n d r e a h e n t z @ u f p a . b r . ~}$
}

RESUMO: A agricultura praticada na região amazônica tem gerado perdas significativas de fertilidade do solo. Para melhorar essas condições busca-se utilizar sistemas agroflorestais, com tecnologias que propiciem a sustentabilidade. A simbiose de plantas com fungos micorrízicos arbusculares (FMA) torna possível o estabelecimento de mudas em solos com condições sub-ótimas devido a uma rede de hifas extracelulares que aumentam a área de absorção das raízes, a melhoria nos aspectos nutricionais da planta que adquirem maior capacidade de sobrevivência a condições adversas. Esses fungos podem ser identificados em laboratório e multiplicados em casa de vegetação. Seus esporos podem ser distribuídos na forma de inoculantes a ser aplicado no recipiente de produção das mudas ou na própria cova de plantio. Esse procedimento acelera a simbiose entre as raízes das plantas e os fungos beneficiando-as muito mais precocemente. Esse tipo de experiências será desenvolvida no Campus da UFPA de Marabá e objetiva implantar uma unidade de produção e distribuição de inoculantes e fungos micorrízicos arbusculares para plantios em SAF de agricultores familiares. Será feita a identificação dos fungos ocorrentes na região a partir de métodos de identificação direta e indireta. Será feita a multiplicação dos fungos em casa de vegetação e produção de inoculante, assim como a produção de mudas inoculadas. Será escolhido Projeto de Assentamento onde será implantado o SAF. Na área escolhida será feita caracterização inicial do solo, em seus aspectos físicos, químicos e biológicos. O SAF será implantado com 4 tratamentos distintos. As mudas, inoculadas ou não, serão produzidas na casa de vegetação da Faculdade de Ciências Agrárias de Marabá - UFPA. O preparo do solo consistirá na aplicação de composto de esterco bovino e húmus de minhoca nas covas de plantio. Serão utilizadas 4 espécies frutíferas cajá (Spondias lutea L.), caju (Anacardium occidentale L.), maracujá (Passiflora edulis) e cupuaçu (Theobroma grandiflorum) e 2 espécies de leguminosas arbóreas leucena (Leucaena sp ) e Acácia (Acacia mangium). A avaliação do SAF experimental será feita a partir dos seguintes indicadores: (1) solo- modificações das qualidades físicas, químicas e biológicas; (2) planta- crescimento da parte aérea, número de folhas, teores de nutrientes na parte aérea e biomassa vegetal, taxas de crescimento anuais, diâmetro do caule a altura do peito, altura, esporulação e colonização micorrízica das mudas; (3) economia - mensuração dos custos de implantação e demanda de força de trabalho familiar; (4) identificação dos agricultores interessados na tecnologia e capacitação e distribuição do inoculante. Será feita a avaliação da ocorrência de fungos micorrízicos arbusculares associados a diversas culturas de interesse agronômico. Espera-se um grande interesse dos agricultores em melhorarem seus sistemas de cultivos, e o projeto será um excelente veículo de disseminação de tecnologias inovadoras de produção. Com esse experimento espera-se conseguir mudas de boa qualidade para agricultores que demonstram interesse nessa tecnologia. É esperada uma boa resposta a esses tratamentos nas espécies cultivadas para que haja boa estabilização e crescimento das plantas com boas condições fitossanitárias e resultados expressivos e, com isso, uma maior disseminação dessa tecnologia visando melhorar as condições de produção da agricultura regional.

PALAVRAS-CHAVE: Insumos biológicos, sustentabilidade, sistemas agroflorestais. 